\title{
The Flypaper Effect Phenomenon: Evidence from Indonesia
}

\author{
Ansharullah Tasri \\ Master of Science in Science of Accounting, Faculty of Economics and Business Universitas Gadjah Mada
}

\begin{abstract}
One of the implementations of autonomy policy is fiscal decentralization. The State gives chance to every local government for improving its fiscal ability. Original Local Government Revenue (PAD) is fiscal potency owned local government to improve local government independence to promote welfare to society. To accelerate fiscal independence of local government equally, the central government sends transfer funds in the form of General Allocation Funds (DAU) which aims to comply local government expenditure that has not fulfilled. However, problems faced is local government expenditure management still much more affected by DAU rather than PAD. It indicates that local government still depends on central government to comply expenditure called flypaper effect. This research aims to analyze the effect of PAD and DAU on local government expenditure by identifying whether occurs flypaper on provincial government in Indonesia. The method used in this research is analysis regression of panel data with Generalized Least Square (GLS). Data used is panel data from 34 provinces in Indonesia between 2008-2017. Based on results estimation, PAD and DAU positively and significantly affect local government expenditure. However, the DAU more affects local government expenditure compared with $P A D$. This exhibits that flypaper effect phenomenon occurred on provincial government in Indonesia which local government expenditure response more affected by DAU than PAD. It is happening due to the provincial government still relies on central government to comply its expenditure illustrated with high DAU transfers. This research concludes that decentralization policy in Indonesia is not effective yet. Thus, the government needs to adjust decentralization policy in order to improve regional fiscal independence.
\end{abstract}

Keywords: Original Local Government Revenue (PAD), General Allocation Fund (DAU), Local Government Expenditure, and Flypaper Effect.

\section{Introduction}

Centralized decentralization in Indonesia has been initiated since the enactment of Law Number 22 the Year 1999 regarding Local Government and Law Number 25 the Year 1999 concerning Financial Balance Between Central and Local Government which is subsequently perfected in Law Number 32 the Year 2004 and Law Number 33 of 2004. This regulation gives the Regional Authority the freedom to administer regional autonomy (Bash, 2015).

One of the implementations of autonomy policy is fiscal decentralization, in which the State provides an opportunity for each region to improve its fiscal capacity with the natural wealth owned for the school which is then earned income used to finance the needs of the region.

Original Local Government Revenue (PAD) is fiscal potency owned local government to improve local government independence to promote welfare to society. To accelerate fiscal independence of local government equally, the central government sends transfer funds in the form of General Allocation Funds (DAU) which aims to comply local government expenditure that has not fulfilled. Intergovernmental assistance within a country or region is very important in a government's 
finances (Deller, Maher, \& Liedo, 2007). With the support given to the local government, it will be able to assist the fiscal activities of local government. Thus the objectives of regional autonomy can function effectively. Regional autonomy can be said to unction effectively if there is no fiscal gap between regions (The World bank, 2007).

Expenditure is the need of every local government to run an economy in a government. With the potential of nature owned, it is expected that local governments can finance their needs. Transfers from the central government are not the primary source of government spending. However, the problem is that the management of regional spending is still more affected by DAU than PAD. This indicates that the local government is still dependent on the central government to meet its spending.

The purpose of this study is to see if there is any inefficiency in the utilization of DAU to the local government at the provincial level. If the effect of DAU transfers has a greater effect on expenditure than the effect of the PAD, the asymmetry of transfer funds is assumed. With an asymmetric response to the increase and decline in the use of transfer funds from the central government resulted in a phenomenon known as the flypaper effect (Turnbull, 1998).

\section{Literature review}

\section{Government Transfer}

There are three categories of transfer allocation models implemented in various countries around the world (Ma, 1997). Application in each country varies depending on the political system, the development and the bureaucracy adopted by each State. The three categories are: (1) Transfer allocation model considering fiscal gap. This model is an ideal model because it is based on the consideration of the difference between fiscal needs and capacity. (2) Transfer allocation model based on fiscal capacity considerations between regions. This model is relatively easier to implement because allocations are more based on inter-regional fiscal capacity but tend to ignore differences in fiscal needs across regions. (3) Transfer allocation model based on various needs indicators. This model allocates transfers as an effort so that each region is able to meet the minimum public service needs.

\section{General Allocation Fund}

The General Allocation Fund (DAU) is the transfer of funds from the central government to the local government which is intended to cover the fiscal gap and the equitable distribution of financial capability among regions in order to support the independence of local governments perform their functions and duties to serve the community. The basic concept of DAU formulation is implicitly the elaboration of the theoretical basis of the fiscal gap conception. With the fiscal gap conception, the fiscal gap which is the negative difference between fiscal needs and fiscal capacity is considered a necessity that must be covered through the Central Government's transfer (Afrizawati, 2012).

\section{Original Local Government Revenue}

The Original Local Government Revenue is revenue that withheld based on local regulations in accordance with the legislation, for the purposes of financing their activities. PAD consists of local taxes, retributions, the income of regional government corporate and management of separated regional government wealth and other local government revenue. Revenue and expenditure relations have been widely discussed in the economic and financial literature since the late 1950s, many empirical hypotheses about this relationship (Chang \& Ho, 2002). Some studies have found that spending affects earnings, while others find that income affects spending. The response has the same distributive and allocative effect as other funding sources (Bradford \& Oates, 1971), such as local revenue.

\section{Local Government Expenditure}

Local Government Expenditure consists of indirect expenditure and direct expenditure. Indirect expenditure is part of personnel expenditure, interest expenditure, subsidies expenditure, grant expenditure, social assistance expenditure, sharing fund expenditure, financial assistance expenditure and unpredicted expenditure. Those items are not directly related to the implementation of programs and activities. Direct expenditure is a part of personnel expenditure, goods and services expenditure, and capital expenditure, that are budgeted directly related to the implementation of programs and activities that are budgeted directly related to the implementation of programs and activities. Government purchases are demand for goods and services (Mankiw, 2013). There are two types of government purchases of goods and services: government consumption and government investment (Amalia, 2015). 


\section{Flypaper Effect}

flypaper effect is an asymmetric response to the increase and decrease in the use of transfer funds from the central government (Turnbull, 1998), whereby the transfer funds are granted for a certain period of time with an indication of a party benefiting from transfer revenues that tend to increase (Afrizawati, 2012). The government is required to be able to minimize the excessive response of funds transfer on local government expenditure. The individual choice theory states that "dollar-to-dollar, matching grants will induce a greater expansion in spending on the will of lump-sum, unconditional grant" (Bradford \& Oates, 1971). However, to analyze the effects of transfer theory is not quite appropriate because grants are not given to individuals, but groups of people (Prakosa, 2004). That is, the effect of grants on expenditure depends on the collective decision-making process by these individuals. Other studies have shown a flypaper effect on DAU utilization. In addition, the results of the study also proved the occurrence of asymmetry in fiscal reimbursement (Junaidi, 2012).

Based on the literature and previous research, this study attempts to analyze Flypaper Effect on the effect of DAU and PAD on provincial government expenditure in Indonesia. So the hypothesis in this study are:

H0: There is no Flypaper Effect on the effect of DAU and PAD on Provincial Government Expenditures.

H1: There is a Flypaper Effect on the effect of DAU and PAD on Provincial Government Expenditures.

\section{Research methods}

Data

The data used are the provincial government financial statistics in Indonesia published by the Indonesian Central Bureau of Statistics through the official web. Processed data are data of General Allocation Fund (DAU), Original Local Government Revenue (PAD), and Local Government Expenditure which is panel data of 34 provinces in Indonesia with time series data from 2008 until 2017 and cross-section data 34 provinces in Indonesia.

\section{Methodology}

The method used in this research is the quantitative method. The method of analysis used in this research is multiple linear regression analysis of panel data analysis with Generalized Least Square (GLS). Flypaper effect testing is done by comparing the effect of DAU on Regional Expenditure and then compared with the effect of PAD on Regional Expenditure. The equations used in this study are as follows:

$$
\begin{array}{ll}
L G E=c+\beta 1 P A D+\beta 2 D A U+\varepsilon \\
L G E & =\text { Local government Expenditure } \\
P A D & =\text { Original Local Government Revenue } \\
D A U & =\text { General Allocation Funds } \\
\varepsilon & =\text { Error Term }
\end{array}
$$

In the equation used will be tested which variable has a greater influence. Flypaper effect occurs when government transfers have a greater impact on local government expenditure (Oates, 1999).

\section{Common Effects Model}

Common effects model is a technique used by combining time series data with cross-section data. This analysis technique is a simple technique to estimate panel data. The time dimension is not considered in this model, the data behavior in this model is assumed to be the same in every period of time. This method can use the Ordinary Least Square (OLS) approach or the least squares technique to estimate the panel data model.

\section{Fixed Effects Model}

To complete the test in this study used fixed effects model to accommodate differences intercept because the common effects model characteristics in each cross section cannot be captured. The common effects model assumes only the same intercepts and slopes in the whole cross-section. To estimate Fixed Effects model panel data, using a dummy variable 
technique to capture inter-province intercept differences, different intercept can occur due to differences in each province. Nevertheless, the slop is the same. This estimation model is often also called the technique of Least Squares Dummy Variable (LSDV).

\section{Random Effects Model}

The addition of variables with dummy variables will give consequences of degrees of freedom this is obtained in the fixed effects model. If the degree of freedom decreases, it will reduce the efficiency of the parameters. In the random effects model, the intercept difference is accommodated by the error terms of each cross section. Required Model specification test on data panel aimed to get the best model to represent data condition. Being tested specification on panel data model with three test types are Chow Test, LM Test, and Hausman Test.

\section{Hausman Test}

In the last step of the selection tool to make estimation that is between the random effects or fixed effects. There are two things to consider in this election is the first whether or not the correlation between error terms and independent variables, if both have a correlation then the most appropriate choice is to use a random effect model. Secondly, if the sample taken is only a small part of the population then it will get random error conditions so that the most appropriate option is to use a random effects model. Formally the test is a Hausman test. The null hypothesis for the Hausman test is based on the idea that both methods are OLS and GLS consistent but OLS is inefficient. Alternative hypothesis is consistent OLS method and inconsistent GLS.

\section{Result and Discussion}

There are three models in panel data analysis that can be used, namely OLS model, fixed effects model, and random effects model. To determine the best model used, can be analyzed with hausman test. From the test results, the results presented show that the most suitable model in this research is to use random effects model with Generalized Least Square method. This test uses data analysis program stata version 13. Table 1 shows the statistical description of the variables test.

Tabel 1

Statistical Description

\begin{tabular}{llll}
\hline Variable & Obs & Mean & Std. Dev. \\
\hline Local Government Expenditure & 340 & $5.52 \mathrm{e}+12$ & $7.41 \mathrm{e}+12$ \\
PAD & 340 & $2.74 \mathrm{e}+12$ & $5.17 \mathrm{e}+12$ \\
DAU & 340 & $8.83 \mathrm{e}+11$ & $5.26 \mathrm{e}+11$ \\
\hline
\end{tabular}

Table 1 shows that the average of local government expenditure provincial in Indonesia per year is 5.52 trillion. While the average PAD and DAU are 2.74 trillion and 8.83 trillion per year. From table 1 show that the average DAU per year in each province in Indonesia is greater than the average PAD each year.

Tabel 2

Estimated Results

\begin{tabular}{llll}
\hline Variable & Fixed Effects & Random Effects & OLS \\
\hline PAD & $1.322154^{*}$ & $1.328553^{*}$ & $1.352901^{*}$ \\
& $(0.0247515)$ & $(0.0229941)$ & $(0.0199973)$ \\
DAU & $2.888425^{*}$ & $2.832855^{*}$ & $2.175892^{*}$ \\
& $(0.1489559)$ & $(0.1455514)$ & $(0.1962795)$ \\
\hline
\end{tabular}

Note: Standard Errors in parentheses

significance: ${ }^{*}<0.1,{ }^{* *}<0.5,{ }^{* *} 0.01$ 
Random Effects estimation results show that PAD has the significant and positive influence on local government expenditure. The value of the variable coefficient exhibit that each increase of PAD one unit then the local government expenditure will increase by 1.328553 units, assuming other variables are considered fixed. DAU has a significant and positive influence on local government expenditure. The value of the variable coefficient indicates that every increase of DAU one unit then the regional spending will increase by 2.832855 units, assuming other variables are considered fixed. From these results, the effect of DAU is greater on regional expenditure than the effect of PAD. Thus there is a flypaper effect on the provincial government in Indonesia.

The results of research indicate that in the provincial-level government in Indonesia occurs flypaper effect phenomenon (receiving $\mathrm{H} 1$ ). In other words, the government's expenditure response in the form of provincial government expenditure is still more influenced by the DAU's effect than it is affected by the PAD effect. This result is in accordance with previous research (Junaidi, (2012), Ndadari \& Adi, (2008), and Afrizawati, (2012)) which concluded that the flypaper effect occurs in the management of local spending.

\section{Conclusion}

The purpose of this study is to test whether there is a flypaper effect on the provincial spending in Indonesia by looking at the implications that arise from the occurrence of flypaper effect. By using the variable of general allocation fund, original local government revenue and local government expenditure, and the result of analysis in the previous section, the conclusion of the result of this research is first, variable General Allocation Fund (DAU) and Original Local Government Revenue (PAD) significantly influence regional expenditure provinces in Indonesia. It is seen that the regional expenditure policy is largely influenced by general allocation funds and original local government revenue, where the greater the revenue received by the province then the regional expenditure will be greater. Second, the test results show the effect of DAU on local government expenditure is greater than the effect of PAD on regional local government expenditure, which means there is flypaper effect on the province in Indonesia. This indicates that provincial governments in Indonesia tend to wait for grants from the central government, but they have not tried optimally to manage natural resource resources aimed at increasing local revenues.

\section{Acknowledgments}

I would like to thank Indonesia Endowment Fund for Education (LPDP) Ministry of Finance of Republic Indonesia for gorgeously supporting the author by scholarship.

\section{References}

[1] Afrizawati. (2012). Analisis Flypaper Effect pada Belanja Daerah Kabupaten/Kota di Sumatera Selatan. Jurnal Ekonomi Dan Informasi Akuntansi, 2: 21-30., 1-20.

[2] Amalia, F. (2015). Analisis Flypaper Effect Pada Belanja Daerah Kabupaten Dan Kota Di Provinsi Banten. Jurnal Organisasi Dan Manajemen, 11(1), 15-25.

[3] Bash, E. (2015). UNDANG-UNDANG REPUBLIK INDONESIA NOMOR 22 TAHUN 1999 TENTANG PEMERINTAHAN DAERAH. PhD Proposal, 1. https://doi.org/10.1017/CB09781107415324.004

[4] Bradford, D. F., \& Oates, W. E. (1971). the Analysis of Revenue Sharing in a New Approach To Collective Fiscal Decisions. Quarterly Journal of Economics, 85(3), 416-439. https://doi.org/10.2307/1885931

[5] Chang, T., \& Ho, Y. H. (2002). Tax or Spend, What Cause What: Taiwan's Experience. International Journal of Business and Economics, 1(2), 157-165.

[6] Deller, S., Maher, C., \& Liedo, V. (2007). Winconsin Local Government, State Shared Revenues and The Illusive Flypaper Effect. Journal of Budgeting, Accounting, and Financial Management, 19(2), 200-220.

[7] Junaidi. (2012). Asimetri pada Flypaper Effect : Bukti Empiris Pemanfaatan Dana Alokasi Umum pada Pemerintah Daerah di Indonesia. Jurnal Akuntansi Dan Keuangan, 14(1), 45-55.

[8] Ma, J. (1997). Intergovernmental Fiscal Transfers in Nine Countries: Lessons for Developing Countries. Policy Research Working Papers- World Bank Wps.

[9] Mankiw. (2013). Mankiw Principles of Economics. Journal of Chemical Information and Modeling (Vol. 53). https://doi.org/10.1017/CB09781107415324.004

[10] Ndadari, L. W., \& Adi, P. H. (2008). PERILAKU ASIMETRIS PEMERINTAH DAERAH TERHADAP TRANSFER PEMERINTAH PUSAT. In The 2nd National Conference UKWMS (p. 24). Retrieved from $\mathrm{https}$ ://scholar.google.co.id/scholar?hl=en\&as_sdt=0\%2C5\&q=perilaku+asimetris+pemerintah+terhadap+transfer+pemerinta h+pusat\&btnG=

[11] Oates, W. E. (1999). An Easy on Fiscal Federalism. Journal of Economic Literature, 37(3), 1120. https://doi.org/Article 
[12] Prakosa, K. B. (2004). ANALISIS PENGARUH DANA ALOKASI UMUM (DAU) DAN PENDAPATAN ASLI DAERAH (PAD) TERHADAP PREDIKSI BELANJA DAERAH (Studi Empirik di Wilayah Propinsi Jawa Tengah dan DIY). Jaai, 8(2), 101-118.

[13] The World Bank. (2007). Desentralisasi Fiskal \& Kesenjangan Daerah. Kajian Pengeluaran Publik, 121.

[14] Turnbull, G. K. (1998). The Overspending and Flypaper Effects of Fiscal Illusion: Theory and Empirical Evidence. Journal of Urban Economics, 44(1), 1-26. https://doi.org/10.1006/juec.1997.2056 